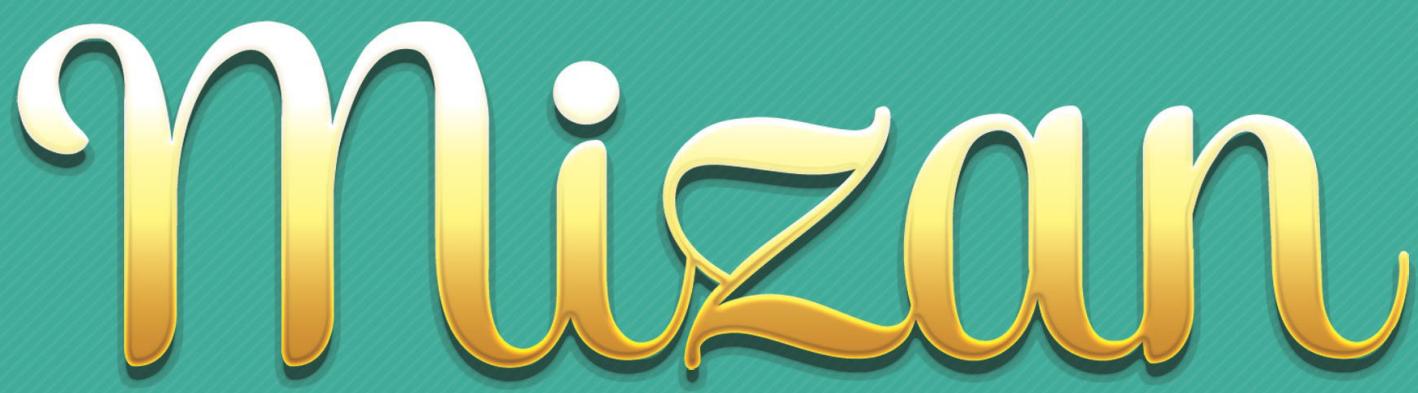

JOURNAL OF ISLAMIC LAW

Diskursus Gender Dalam Hukum Islam Mesraini

Studi Komparatif Antara Hukum Islam dan Hukum Perdata Belanda (BW)

Tentang Wali Nikah Bagi Anak Angkat

Rizky Nanda, Syarifah Gustiawati Mukri

Selisik Upaya Pencegahan Korupsi dan Gratifikasi

Di Kota Tangerang Selatan Banten

Supriyadi Ahmad, Yuniati Nuraini

Studi Komparatif Pemikiran Imam Nawawi dan Yusuf al-Qardhawi

Tentang Berjabat Tangan Dengan Bukan Mahram Dalam Islam

Dani Ahmad Ramdani, Sutisna

Ilhaq Hukum Pada Masyarakat Multi Kultur Indonesia;

Pemikiran Hukum Muhammad Hasyim Asy'ari 1871-1947 M

Qosim Arsadani AS

Makna Fii Sabilillah Sebagai Mustahiq Zakat

Perspektif Sayyid Abu Bakar Asy-Syatho dan Yusuf Qardhawi

Muhammad Hafizhuddin Hazazi, Suyud Arif, Sutisna

Transaksi Tanpa ljab Kabul

Dalam Masyarakat Perspektif Hukum Islam

Ahmad Mukri Aji

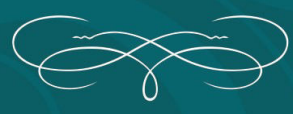

Fakultas Agama Islam

Universitas Ibn Khaldun

Bogor 


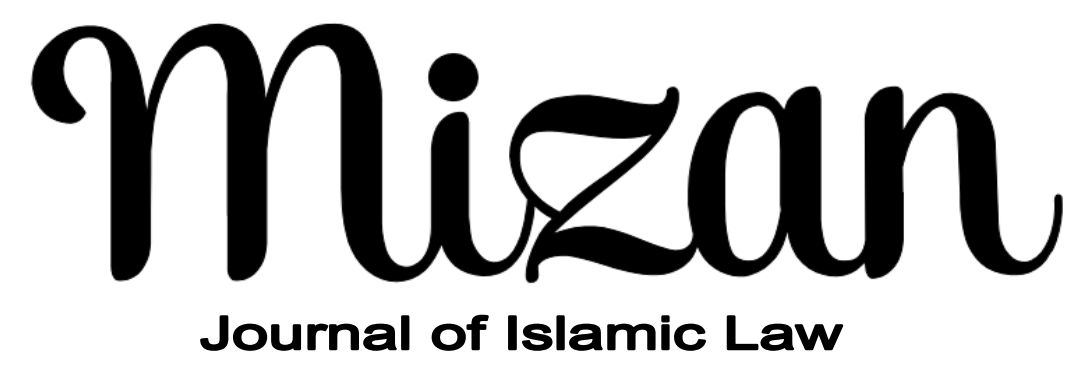

\section{VOL. 2 NO. 1 (2018)}

Mizan: Journal of Islamic Law is continuation of Mizan Ahwal Al-Syakhsiyah Journal since 2013, published by the faculty of Islamic Studies, Universitas Ibn Khaldun (UIKA) Bogor West Java, Indonesia. Mizan of Islamic Law published twice a year since 2017 (June and Desember), is a multilingual (Bahasa Indonesia, Arabic, English, and

Russian), Peer-Reviewed journal, and specialized in Islamic Law, Islamic Studies, and Sharia. This journal is published by the faculty of Islamic Studies, Universitas Ibn Khaldun Bogor, in partnership with APSI (Indonesian Sharia Advocates Association). Editors welcome scholars researchers and pratitioner of Islamic Law around the world to submit scholarly articles to be published throught this journal. All articles will be reviewed by experts before accepted for publication, each author is solely responsible for the content of published articles.

MIZAN; Journal of Islamic Law has been indexed at Google Scholar, Moraref, Sinta, and become a CrossRef Member since year 2017. Therefore, all articles published by MIZAN; Journal of Islamic Law will have unique DOI number.

[ISSN: 2598-974X, E-ISSN: 2598-6252]

\section{ADVISORY EDITORIAL BOARD}

Didin Hafidhuddin (Universitas Ibn Khaldun Bogor)

Muhammad Munir (International Islamic University Islamabad, Pakistan)

Andi Salman Maggalatung (UIN Syarif Hidayatullah Jakarta)

Ending Bahruddin (Universitas Ibn Khaldun Bogor)

Ahmad Mukri Aji (UIN Syarif Hidayatullah Jakarta)

Muhammad Kholil Nawawi (Universitas Ibn Khaldun Bogor)

Hendri Tanjung (Universitas Ibn Khaldun Bogor)

Irfan Syauqi Beik (Institut Pertanian Bogor)

Nur Rohim Y (Kazan Federal University, KFU Russia)

\section{EDITOR IN CHIEF}

Syarifah Gustiawati Mukri

$$
\begin{gathered}
\text { EDITORS } \\
\text { Suyud Arif } \\
\text { Sutisna } \\
\text { Yono }
\end{gathered}
$$

\section{ASSISTANT TO THE EDITORS}

Siti Anisaul Kamilah

\section{Redaktur Office}

Fakultas Agama Islam Universitas Ibn Khaldun Bogor Jawa Barat

Jl. KH. Sholeh Iskandar KM. 2 Kedung Badang Tanah Sareal Bogor 16162

Telp. (62-251) 8356884, Faks. (62-251) 8356884

Website: http://www.jurnalfai-uikabogor.org/index.php/mizan,

E-mail: jurnalmizan.uikabogor@gmail.com

Permalink: https://uika-bogor.academia.edu/JurnalMizanUIKABogor 


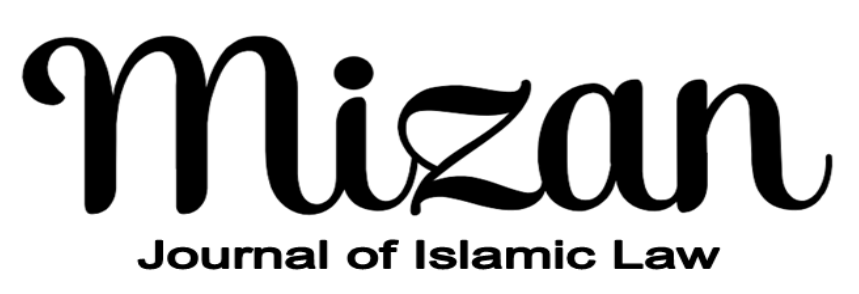

Menyambut baik kontribusi dari para ilmuwan, sarjana, profesional, dan peneliti dalam disiplin ilmu hukum untuk dipublikasi dan disebarluaskan setelah melalui mekanisme seleksi naskah, telaah mitra bebestari, dan proses penyuntingan yang ketat. 


\section{DAFTAR ISI}

1 Diskursus Gender Dalam Hukum Islam

(Gender Discourse in Islamic Law)

Mesraini

13 Studi Komparatif Antara Hukum Islam dan Hukum Perdata Belanda (BW) Tentang Wali Nikah Bagi Anak Angkat

(Comparative StudyBetween Islamic Law and Dutch Civil Law (BW) About Marriage Guardians for Adopted Children)

Rizky Nanda, Syarifah Gustiawati Mukri

29 Selisik Upaya Pencegahan Korupsi dan Gratifikasi Di Kota Tangerang Selatan Banten

(Efforts to Prevent Corruption and Gratification in South Tangerang City of Banten) Supriyadi Ahmad, Yuniati Nuraini

47 Studi Komparatif Pemikiran Imam Nawawi dan Yusuf al-Qardhawi Tentang Berjabat Tangan Dengan Bukan Mahram Dalam Islam

(Comparative Study of Imam Nawawi and Yusuf al-Qardhawi about Shaking Hands Not Mahram in Islam)

Dani Ahmad Ramdani, Sutisna

59 Ilhaq Hukum Pada Masyarakat Multi Kultur Indonesia; Pemikiran Hukum Muhammad Hasyim Asy'ari 1871-1947 M

(Ilhaq Law in Multi Culture Society of Indonesia; Legal Thought Muhammad Hasyim Asy'ari 1871-1947)

Qosim Arsadani AS

75 Makna Fii Sabilillah Sebagai Mustahiq Zakat Perspektif Sayyid Abu Bakar Asy-Syatho dan Yusuf Qardhawi

(The Meaning of Fi Sabilillah As Mustahiq Zakat Perspective Sayyid Abu Bakar AsySyatho and Yusuf Qardhawi)

Muhammad Hafizhuddin Hazazi, Suyud Arif, Sutisna

91 Transaksi Tanpa Ijab Kabul Dalam Masyarakat Perspektif Hukum Islam

(Unsolicited-Qabul Transaction in Society Perspective of Islamic Law)

Ahmad Mukri Aji 



\title{
Selisik Upaya Pencegahan Korupsi dan Gratifikasi Di Kota Tangerang Selatan Banten ${ }^{\star}$ (Efforts to Prevent Corruption and Gratification In South Tangerang City of Banten)

\author{
Supriyadi Ahmad, Yuniati Nuraini
} \\ Universitas Islam Negeri Syarif Hidayatullah Jakarta \\ Jl. Ir. H. Juanda No. 95 Ciputat Tangsel \\ E-mail: supriyadi.ahmad@uinjkt.ac.id, yuniati.nuraini@gmail.com
}

\section{DOI: https://doi.org/10.32507/mizan.v2i1.211}

\begin{abstract}
:
The rise of corruption and gratification in Indonesia has caused this country to be ranked 97th out of 176 countries in this crime. Such thing inspired the City Administration of South Tangerang, Banten to make efforts to prevent corruption and gratification within the State Civil Apparatus (ASN) and government officials in this region. These efforts are the Issuance of Mayor Regulation Number 17 of 2017 and the Mayor's Decree which regulates gratification Number 700 / Kep.188-Huk / 2015. These efforts were carried out intensively and significantly succeeded in preventing corruption and gratification in the South Tangerang Government area, although there were some things that still needed to be improved. Among the obstacles to preventing corruption and gratification in South Tangerang are religious and ethical education and several other obstacles.
\end{abstract}

Keywords: Corruption Prevention, Gratification, South Tangerang

\begin{abstract}
Abstrak:
Maraknya korupsi dan gratifikasi di Indonesia menyebabkan negeri ini masih terpuruk ke peringkat 97 dari 176 negara di dunia dalam tindak pidana ini. Hal seperti itu menginspirasi Pemerintah Kota Administratif Tangerang Selatan, Banten untuk melakukan upaya-upaya pencegahan korupsi dan gratifikasi di lingkungan Aparatur Sipil Negara (ASN) dan pejabat pemerintah di wilayah ini. Upaya-upaya tersebut adalah Penerbitan Peraturan Walikota Nomor 17 Tahun 2017 dan Keputusan Walikota yang mengatur tentang gratifikasi Nomor 700/Kep.188-Huk/2015. Upaya-upaya tersebut dilakukan secara intensif dan berhasil secara signifikan dalam pencegahan korupsi dan gratifikasi di wilayah Pemerintahan Tangerang Selatan, meskipun ada beberapa hal yang masih perlu diperbaiki. Di antara kendala pencegahan korupsi dan gratifikasi di Tangerang Selatan adalah pendidikan agama dan etika dan beberapa kendala lainnya.
\end{abstract}

Kata Kunci: Pencegahan Korupsi, Gratifikasi, Tangerang Selatan

${ }^{*}$ Naskah diterima tanggal: 18 Maret 2018, direvisi: 20 Mei 2018, disetujui untuk terbit: 11 Juni 2018. 


\section{Pendahuluan}

Sungguh sangatlah mencengangkan bila Indonesia pada tahun 2017 menempati urutan ke-90 dari 176 negara di dunia ${ }^{1}$ yang diukur tingkatan korupsinya. Inilah rilis Transparency International Indonesia (TII) yang menyebutkan bahwa pada tahun 2017 Indonesia menambah skor 37 poin yang diperoleh melalui survei yang dilakukan di sepuluh kota di Indonesia. Meski naik satu poin dari tahun 2016, secara global, Indonesia masih terpuruk dalam peringkat korupsi di dunia.

Bangsa Indonesia dan mata manusia sedunia mungkin akan terbelalak ketika melihat data bahwa secara kuantitatif, ternyata hanya dalam kurun waktu setengah tahun, sejak 1 Januari 2018 sampai 21 Juni 2018, terdapat gratifikasi sebanyak 798 laporan yang diterima oleh KPK (Komisi Pemberantasan Korupsi). Nilainya juga cukup fantastis, yaitu Rp 7,2 miliar.2 Gratifikasi seperti yang dijelaskan di atas merupakan bentuk korupsi yang dilakukan oleh seseorang atau korporasi dengan memberikan sesuatu kepada Aparatur Sipil Negara (ASN) atau pejabat negara tertentu karena ASN atau pejabat negara tersebut dianggap telah memberikan kemudahan atau keuntungan tertentu kepada pemberi gratifikasi.

Secara yuridis formal, dalam Penjelasan Pasal 12 B Ayat (1) UndangUndang Nomor 31 Tahun 1999 juncto Undang-Undang Nomor 20 Tahun 2001, bahwa gratifikasi adalah seperti yang diuraikan sebagai berikut:

"Yang dimaksud dengan "gratifikasi" dalam ayat ini adalah pemberian dalam arti luas, yakni meliputi pemberian uang, barang, rabat (discount), komisi, pinjaman tanpa bunga, tiket perjalanan, fasilitas penginapan, perjalanan wisata, pengobatan cuma-cuma, dan fasilitas lainnya. Gratifikasi tersebut baik yang diterima di dalam negeri maupun di luar negeri dan yang dilakukan dengan menggunakan sarana elektronik atau tanpa sarana elektronik."3

Di berbagai daerah, termasuk Pemerintahan Kota Tangerang Selatan, terdapat banyak bentuk korupsi dan gratifikasi. Bagaimanakah upaya yang dilakukan oleh Pemerintah Kota Tangerang Selatan dalam pencegahan korupsi dan gratifikasi? Bagaimanakah keberhasilan upaya-upaya Pemeritah Kota Administratif Tangerang Selatan? Apa sajakah kendala yang dihadapi Pemerintah kota ini dalam upaya pencegahan korupsi dan gratifikasi? Dalam makalah ini akan diselisik atau disingkap hal-hal tersebut untuk dapat diambil nilai-nilainya secara akademis dan praktis.

${ }^{1}$ Uraian lengkap dapat dilihat pada laman http://www.bbc.com/indonesia/indonesia38734494. Diunduh oleh penulis utama pada hari Senin, 09 Juli 2018 pukul 14:44 WIB.

2 Lihat selengkapnya pada laman https://www.republika.co.id/berita/nasional/hukum /18/06/22/papygi409-kpk-terima-798-laporan-gratifikasi-senilai-rp-72-miliar (Sabtu 23 June 2018 02:18 WIB).

${ }^{3}$ Komisi Pemberantasan Korupsi (KPK), Buku Saku Memahami Gratifikasi, Gratifikasi Adalah Akar dari Korupsi, Jakarta: Komisi Pemberantasan Korupsi (KPK), 2014, hal. 3. 


\section{Selisik Korupsi dan Gratifikasi}

Korupsi merupakan momok bagi semua bangsa di dunia. Bahkan, dapat dipastikan bahwa semua agama di dunia melarang korupsi. Menurut Kamus Besar Bahasa Indonesia (kkbi) Dalam Jaringan, korupsi "penyelewengan atau penyalahgunaan uang negara (perusahaan, organisasi, yayasan dan sebagainya) untuk keuntungan pribadi atau orang lain". ${ }^{4}$ Sedangkan gratifikasi menurut sumber yang sama adalah "pemberian yang diberikan karena layanan atau manfaat yang diperoleh" ${ }^{5}$ Lebih luas lagi, dalam Buku Saku KPK, dijelaskan bahwa gratifikasi menurut penjelasan Pasal 12B UU No. 20 Tahun 2001, adalah pemberian dalam arti luas, yakni meliputi pemberian uang, barang, rabat (discount), komisi, pinjaman tanpa bunga, tiket perjalanan, fasilitas penginapan, perjalanan wisata, pengobatan cuma-cuma, dan fasilitas lainnya. ${ }^{6}$ Gratifikasi tersebut baik yang diterima di dalam negeri maupun di luar negeri dan yang dilakukan dengan menggunakan sarana elektronik atau tanpa sarana elektronik.

Transparansi Internasional Indonbesia memberikan definisi tentang korupsi sebagai perbuatan menyalahgunakan kekuasaan dan kepercayaan publik untuk keuntungan pribadi. ${ }^{7}$ Dalam definisi ini terdapat beberapa unsur dari pengertian korupsi, yaitu menyalahgunakan kekuasaan, kekuasaan yang dipercayakan memiliki akses bisnis atau keuntungan materi dan keuntungan pribadi. AS Hornby E.V. Gatenby and H. Wakefield sebagaimana dikutip oleh Baharuddin Lopa korupsi adalah the offering and acceptimg of bibes (penawaran/pemberian dan penerimaan suap). Dikatakan juga, "corruptionis decay" yang berarti kebusukan atau kerusakan. ${ }^{8}$ Sudah barang tentu yang dimaksudkan "busuk" atau "rusak" itu, ialah moral atau akhlak dari oknum yang melakukan perbuatan korupsi tersebut. ${ }^{9}$

Dalam Undang-undang Republik Indonesia Nomor 31 Tahun 1999 tentang Pemberantasan Tindak Pidana Korupsi, pasal 3 ayat 1 juga dijelaskan tentang definisi korupsi. Dalam undang-undang itu disebutkan bahwa korupsi adalah setiap tindakan dengan tujuan menguntungkan diri sendiri atau orang lain atau suatu korporasi, menyalahgunakan kewenangan, kesempatan, atau

${ }^{4}$ Lihat https://kbbi.kemdikbud.go.id/entri/korupsi diunduh hari Senin, 09 Juli 2018 pukul 12:36 wib oleh penulis utama.

${ }^{5}$ Lihat https://kbbi.kemdikbud.go.id/entri/korupsi diunduh hari Senin, 09 Juli 2018 pukul 12:49 wib oleh penulis utama.

6 Selengkapnya dapat dilihat pada laman http://rb.pom.go.id/id/content/delapan-areaperubahan/memahami-gratifikasi

7 Jeremy Pope, Strategi Memberantas Korupsi (Edisi Ringkas) dengan judul asli Confloring Corruption: Element of Nation Integrity System, by Jeremy Pope. Diringkas oleh Tjahjono EP, Jakarta: Transparancy International Indonesia, 2003, hal. 6.

8 Publication City/Country Oxford, The Advanced Learner's Dictionary of Current English, Oxford: United Kingdom, 2015, hal. 218.

${ }_{9}$ Baharuddin Lopa, Kejahatan Korupsi dan Penegakan Hukum, Jakarta: PT Kompas Media Nusantara, 2001, hal. 67. 
sarana yang ada padanya karena jabatan atau kedudukan yang dapat merugikan keuangan negara atau perekonomian negara. ${ }^{10}$

Menurut Mubyarto, korupsi adalah suatu masalah politik lebih dari pada ekonomi yang menyentuh keabsahan (legitimasi) pemerintah di mata generasi muda, kaum elite terdidik dan para pegawai pada umumnya. Akibat yang ditimbulkan dari korupsi ini ialah berkurangnya dukungan pada pemerintah dari kelompok elite di tingkat provinsi dan Kota atau Kabupaten. Pengertian korupsi yang diungkapkan Mubyarto yaitu menyoroti korupsi dari segi politik dan ekonomi. ${ }^{11}$ Syeh Hussein Alatas mengemukan pengertian korupsi, menurut beliau korupsi ialah subordinasi kepentingan umum di bawah kepentingan pribadi yang mencakup pelanggaran norma, tugas dan kesejahteraan umum, yang dilakukan dengan kerahasian, penghianatan, penipuan dan kemasabodohan akan akibat yang diderita oleh rakyat. ${ }^{12}$

Dalam Undang-Undang Nomor 31 Tahun 1999 juncto Undang-Undang Nomor 20 Tahun 2001 tentang Pemberantasan Tindak Pidana Korupsi, ada 30 jenis tindak pidana korupsi. Ke-30 jenis tindak pidana korupsi tersebut pada dasarnya dapat dikelompokkan menjadi tujuh, yaitu: 1) kerugian keuangan Negara; 2) suap-menyuap; 3) penggelapan dalam jabatan; 4) pemerasan; 5) perbuatan curang; 6) benturan kepentingan dalam pengadaan; dan 7) gratifikasi.

Dengan demikian, kedua-duanya-korupsi dan gratifikasi sama-sama menjadikan jabatan, kekuasaan, dan wewenang sebagai motif dari suatu pemberian atau hadiah, tetapi gratifikasi sebenarnya adalah bagian dari korupsi itu sendiri. Terdapat perbedaan antara korupsi dan gratifikasi, meskipun disebutkan bahwa gratifikasi adalah akar dari korupsi. Dalam korupsi ada unsur "mengetahui atau patut dapat menduga" sehingga ada intensi atau maksud untuk mempengaruhi pejabat publik dalam kebijakan maupun keputusannya. Sedangkan untuk gratifikasi, diartikan sebagai pemberian dalam arti luas, tetapi dapat dianggap sebagai suap apabila berhubungan dengan jabatannya dan yang berlawanan dengan kewajiban atau tugasnya.

Dalam pengertian sederhana, korupsi adalah penyalahgunaan kekuasaan dan kepercayaan untuk kepentingan pribadi. Karena itu korupsi dipahami dalam konteks perilaku pejabat-pejabat sektor publik, politisi, pegawai negeri yang memakai kekuasaan dan wewenang sosial untuk memperkaya diri, atau bersama orang-orang yang dekat dengan mereka. Dengan demikian, ha itu

10 Selengkapnya dapat dilihat pada situs resmi KPK (Komisi Pemberantaan Korupsi) yang diunduh oleh penulis pada hari Rabu, tanggal 31 Januari 2018, pukul. 10:34 WIB dengan alamat https://www.kpk.go.id/images/pdf / Undang-undang/uu311999.pdf

${ }_{11}$ Andi Hamzah, Pemberantasan Korupsi Melalui Hukum Pidana Nasional dan Internasional. Jakarta: PT Raja Grafindo Persada, 2007, hal. 11.

${ }_{12}$ Andi Hamzah, Pemberantasan Korupsi Melalui Hukum Pidana Nasional dan Internasional, hal. 11. 
merupakan tindakan melawan hukum, melawan norma, melawan kepatutan, dan melawan keseimbangan kosmos. ${ }^{13}$

Berdasarkan bentuknya korupsi dapat dibagi dua, yaitu: pertama, yang lebih banyak menyangkut penyelewengan di bidang materi (uang) yang dikategorikan material corruption. Kedua, berupa perbuatan memanipulasi pemungutan suara dengan cara penyuapan, intimidasi, paksaan, dan/atau campurtangan yang dapat mempengaruhi kebebasan meimilih, komersialisasi pemungutan suara pada lembaga legislatif atau pada keputusan yang bersifat administratif, janji jabatan dan sebagainya, yang dikategorikan political corruption. Ketiga, yang memanipulasi ilmu pengetahuan seperti apabila seseorang memberikan informasi atau penerangan sesuatu yang berhubungan denga ilmu pengetahuan dengan cara yang tidak sebenarnya yang biasanya dilator belakangi oleh kepentingan-kepentingan tertentu. ${ }^{14}$

Berdasarkan sifat atau motifnya, korupsi dibedakan menjadi dua, yaitu: pertama, korupsi yang bermotif terselubung. Korupsi seperti ini, ialah korupsi yang secara sepintas lalu kelihatannya bermotif politik, tetapi secara tersembunyi sesungguhnya bermotif mendapatkan uang semata-mata. ${ }^{15}$

Berdasarkan subjek hukum tindak pidana korupsi salah satunya yang akan penulis bahas adalah tindak pidana korupsi pegawai negeri dana tau penyelenggara negara yaitu, adalah tindak pidana korupsi yang hanya dapat dilakukan oleh orang yang berkualitas sebagai pegawai negeri atau penyelenggara negara. Artinya, tindak pidana yang dirumuskan itu semata-mata dibentuk untuk pegawai negeri atau penyelenggara negara. Orang yang bukan pegawai negeri tidak dapat melakukan tindak pidana korupsi pegawai negeri ini. Tindak pidana korupsi ini merupakan bagian dari kejahatan jabatan atau dapat disebut sebagai kejahatan khusus. ${ }^{16}$

Pada undang-undang tersebut setiap gratifikasi yang diperoleh pegawai negeri atau penyelenggara negara dianggap suap, namun ketentuan yang sama tidak berlaku apabila penerima melaporkan gratifikasi yang diterimanya kepada Komisi Pemberantasan Korupsi (KPK), dan wajib dilaporkan paling lambat 30 (Tiga puluh) hari kerja terhitung sejak tanggal gratifikasi tersebut diterima. ${ }^{17}$

${ }^{13}$ Supriyadi Ahmad, "Dari Mahar Politik Hingga Mental Politik Transaksional: Kajian Komparatif Tentang Korupsi Di Era Milenial Indonesia", diakses dari http://www.jurnalfaiaikanogor.org (Mizan: Jurnal Ilmu Syariah, FAI Universitas Ibn Khaldun UIKA Bogor Vol.5 No.1, 2017) diakses pada 12 Februari 2018 pukul 20.00 wib.

${ }^{14}$ Baharuddin Lopa, Kejahatan Korupsi dan Penegakan Hukum, Jakarta: PT Kompas Media Nusantara, 2001, hal. 70.

${ }^{15}$ Baharuddin Lopa, Kejahatan Korupsi dan Penegakan Hukum, hal. 71.

16 Adami Chazawi, Hukum Pidana Materil dan Formil Korupsi di Indonesia, (Malang: Bayumedia Publishing, 2005), hal. 23.

17 Komisi Pemberantasan Korupsi, Buku Saku Memahami Gratifikasi, (Jakarta: Komisi Pemberantasan Korupsi Republik Indonesia, 2014), hal. 3. 
Apabila dicermati penjelasan di atas, kalimat yang termasuk definisi gratifikasi adalah sebatas kalimat: pemberian dalam arti luas, sedangkan kalimat setelah itu merupakan bentuk- bentuk gratifikasi. Dari penjelasan pasal diatas juga dapat dilihat bahwa pengertian gratifikasi mempunyai makna yang netral, artinya tidak terdapat makna tercela atau negatif dari arti kata gratifikasi tersebut. Apabila penjelasan ini dihubungkan dengan rumusan pasal 12B dapat dipahami bahwa tidak semua gratifikasi itu bertentangan dengan hukum, melainkan hanya gratifikasi yang memenuhi kriteria dalam unsur pasal 12B saja. ${ }^{18}$ Sedangkan seorang Plato pun memiliki gagasan mengenai gratifikasi, yaitu "Para pelayan bangsa harus memberikan pelayanan mereka tanpa menerima hadiah". ${ }^{19}$ Gagasan tersebut menggambarkan bahwa tidak sepantasnya pegawai negeri atau pejabat negara menerima hadiah dari pelayanan yang mereka berikan. Sehingga pelayanan terhadap masyarakat menjadi lebih baik dan bebas dari korupsi

Dalam istilah hukum, pemberian hadiah kepada pejabat atau penyelenggaraan negara dikenal dengan istilah popular yaitu "gratifikasi", yang berasal dari bahasa Belanda "gratikatie" yang diadopsi dalam bahasa Inggris menjadi "gratification" yang artinya "pemberian sesuatu/hadiah". Black's Law Dictionary memberikan definisi gratifikasi atau gratification adalah sebagai " $a$ voluntarily given reward or recompense for a service or benefit" yang dapat diartikan sebagai "ssebuah pemberian yang diberikan atas diperolehnya suatu bantuan atau keuntungan". ${ }^{20}$

Gratifikasi sebagai bentuk perbuatan hukum yang mengatur dan terkait dengan penyelenggaraan negara diatur dalam UU No 20 tahun 2001, dalam Pasal 12 B setiap gratifikasi kepada pegawai negeri atau penyelenggara negara dianggap pemberian suap, apabila berhubungan dengan jabatannya dan berlawanan dengan kewajiban atau tugasnya.

Maka dapat dikatakan bahwa suatu gratifikasi atau pemberian hadiah berubah menjadi suatu perbuatan pidana suap khususnya pada seorang penyelenggara negara atau pegawai negari adalah pada saat penyelenggaraan negara atau pegawai negeri tersebu melakukan tindakan menerima gratifikasi atau pemberian hadiah dari pihak manapun sepanjang pemberian tersebut berhubungan dengan jabatannya ataupun pekerjaannya. ${ }^{21}$

\footnotetext{
${ }^{18}$ Komisi Pemberantasan Korupsi, Buku Saku Memahami Gratifikasi, hal. 3.

${ }^{19}$ Arya Maheka, Mengenal dan Memberantas Korupsi, (Jakarta: Veteran III,tt), hal. 21.

${ }^{20}$ Barda Nawawi Arief, Kapita Selekta Hukum Pidana, cet. Ke-I, (Bandung: Citra Aditya Bakti, 2003), h.109.

${ }^{21}$ Darwan Prinst, Pemberantasan Tindak Pidana Korupsi (Bandung: PT. Citra Aditya Bakti, 2002), h.29.
} 
Penerimaan gratifikasi dapat dikategorikan menjadi dua kategori yaitu Gratifikasi yang Dianggap Suap dan Gratifikasi yang Tidak Dianggap Suap yaitu ${ }^{22}$ :

a. Gratifikasi yang Dianggap Suap Yaitu gratifikasi yang diterima oleh Pegawai Negeri atau Penyelenggara Negara yang berhubungan dengan jabatannya dan yang berlawanan dengan kewajiban atau tugasnya,

b. Gratifikasi yang Tidak Dianggap Suap. Yaitu gratifikasi yang diterima oleh Pegawai Negeri atau Penyelenggara Negara yang berhubungan dengan jabatan dan tidak berlawanan dengan kawajiban atau tugasnya.

Gratifikasi sebagai sebuah bentuk perbuatan hukum yang mengatur dan terkait dengan penyelenggaraan negara diatur dalam Undang-Undang Nomor 20 Tahun 2001, dalam Pasal 12 B setiap gratifikasi kepada pegawai negeri atau penyelenggara negara dianggap pemberian suap, apabila berhubungan dengan jabatannya dan berlawanan dengan kewajiban atau tugasnya. Dengan ketentuan sebagai berikut:

1) Yang nilainya Rp. $10.000 .000,00$ (sepuluh juta rupiah) atau lebih, pembuktian bahwa gratifikasi tersebut bukan merupakan suap dilakukan oleh penerima gratifikasi

2) Yang nilainya kurang dari Rp. 10.000.000,00 (sepuluh juta rupiah), pembuktian bahwa gratifikasi tersebut suap dilakukan oleh penuntut umum.

Untuk mengetahui kapan gratifikasi menjadi kejahatan korupsi, perlu dilihat rumusan Pasal 12 B Ayat (1) Undang-Undang Nomor 31 Tahun 1999 jo Undang-Undang Nomor 20 Tahun 2001.

a) Setiap gratifikasi pada pegawai negeri atau penyelenggara negara dianggap pemberian suap, apabila berhubungan dengan jabatannya dan yang berlawanan dengan kewajiban atau tugasnya dengan ketentuan sebagaimana dijelaskan diatas.

b) Pidana bagi pegawai negeri atau penyelenggara negara sebagaimana dimaksud dalam ayat (1) adalah pidana penjara seumur hidup atau pidana penjara paling singkat 4 (empat) tahun, dan paling banyak 20 (dua puluh) tahun dan denda paling sedikit Rp. 200.000.000,00 (dua ratus juta rupiah) dan paling banyak Rp. 1.000.000.000,00 (satu milyar rupiah). ${ }^{23}$

Berdasarkan hal tersebut maka terlihat bahwa ada dua istilah dalam undang-undang Tindak Pidana Korupsi terkait pemberian hadiah kepada pejabat atau penyelenggara negara yaitu gratifikasi dan suap. Sehingga dapat disimpulkan tidak benar bila Pasal 12 B dalam Undang-Undang Nomor 31

${ }^{22}$ Komisi Pemberantasan Korupsi, Buku Saku Memahami Gratifikasi, h.3.

23 Tim Redaksi Fokus Media, Himpunan Peraturan Peundang-Undangan dengan Pemberantasan Tindak Pidana Korupsi, (Bandung: Fokus Media, 2008), h.87. 
Tahun 1999 jo Undang-Undang Nomor 20 Tahun 2001 telah melarang praktik gratifikasi atau pemberian hadiah di Indonesia, sesungguhnya praktik gratifikasi atau pemberian hadiah di kalangan masyarakat tidak dilarang, tetapi perlu diperhatikan adanya sebuah rambu tambahan yaitu larangan bagi ASN atau penyelenggara negara untuk menerima gratifikasi yang dianggap suap. ${ }^{24}$ Karena begitu kompleknya persoalan korupsi dan gratifikasi, maka Pemerintah Kota Administratif Tangerang Selatan mengupayakan pecegahan korupsi dan gratifikasi seperti berikut ini.

\section{Upaya Pencegahan Korupsi dan Gratifikasi di Kota Tangerang Selatan}

Kota Tangerang Selatan adalah sebuah wilayah Kota Administratif yang terletak di Tatar Pasundan Provinsi Banten. Kota ini terletak di sebelah barat Jakarta, dan $90 \mathrm{~km}$ di sebelah tenggara kota Serang yang menjadi ibu kota Provinsi Banten. Wilayah kota Administrati Tangerang Selatan ini merupakan wilayah pemekaran dari Kabupaten Tangerang. ${ }^{25}$ Visi Pemerintah Kota ini adalah Terwujudnya Tangerang Selatan Kota Cerdas, Berkualitas dan Berdaya Saing Berbasis Teknologi dan Inovasi.

Karena lemahnya pendidikan agama dan etika, serta kurang tegas dan beratnya sanksi korupsi dan gratifikasi, maka di Kota Administratif Tangerang Selatan korupsi meningkat. ${ }^{26}$ Oleh karena itu, dibuatlah program pencegahan korupsi dan gratifikasi, yaitu dengan:

\section{Penerbitan Peraturan Walikota dan Keputusan Walikota yang mengatur tentang gratifikasi}

Terbitnya Peraturan Wali Kota Tangerang Selatan Nomor 17 Tahun 2017 tentang pedoman pengendalian gratifikasi dan Keputusan Wali Kota Tangerang Selatan Nomor 700/Kep.188-Huk/2015 tentang pembentukan unit pengendalian gratifikasi. Hal ini merupakan tindakan tegas pemerintah Kota Tangerang selatan dalam upaya pencegahan tindak gratifikasi.

\section{Pembentukan Unit Pengendalian Gratifikasi}

Berdasarkan Keputusan Walikota Tangerang Selatan Nomor 700/Kep.188Huk/2015 tentang pembentukan unit pengendalian gratifikasi merupakan sebuah langkah awal yang diambil pemerintah kota Tangerang Selatan dalam upaya menanggulangi korupsi khususnya gratifikasi, di dalam kebijakan ini 2002), h.29.

${ }^{24}$ Darwan Prinst, Pemberantasan Tindak Pidana Korupsi, (Bandung: PT. Citra Aditya Bakti,

${ }^{25}$ Kota Tangerang Selatan, "Profil Kota Tangerang Selatan" diakses tanggal 9 Maret 2018 pukul 16.30 WIB dari https://id.wikipedia.org/

${ }_{26}$ Pemerintah Kota Tangerang Selatan, "Faktor Meningkatnya Korupsi” diakses tanggal 5 Mei 2018 pukul.20.00 WIB https://www.tangerangselatankota.go.id/pemkot-tangerang-paparkanrencana-aksi-pemberantasan-korupsi-terintegrasi. 
pemerintah kota Tangerang Selatan mengatur tentang seluk beluk pemberian gratifikasi serta pembentukan Unit Pengendalian Gratifikasi sebagai suatu susunan keanggotaan yang bertanggung jawab atau fokus kepada upaya pencegahan gratifikasi.

\section{Pembentukan Tunas Anti Korupsi}

Dalam rangka meningkatkan pengetahuan di lingkungan Pemerintah Kota Tangerang Selatan tentang pemahaman integritas dan aplikasinya, Pemkot melalui Inspektorat menyelenggarakan pelatihan tunas integritas yang berlangsung selama dua hari bertempat di Aula Pemkot Tangsel.

Melalui kegiatan ini diharapkan peserta dapat menjadi agen perubahan (agent of change) dalam kehidupan organisasi dan pencapaian tujuan organisasi. Hadir dalam kegiatan tersebut tim tunas integritas dari Komisi Pemberantasan Korupsi (KPK), dari Kementerian Pendidikan, dan tim integritas dari Palembang.

Wakil Walikota Tangsel Benyamin Davnie mengungkapkan, workshop ini bertujuan untuk menanamkan nilai-nilai anti korupsi dengan mendorong tumbuhnya program “Tunas Integritas" di Kota Tangsel. ${ }^{27}$

\section{Optimalisasi Kinerja APIP}

Bagian auditor pemerintah kota Tangerang Selatan sedang memperkuat APIP (Aparat Pengawasan Internal Pemerintah) dengan memperbanyak anggota dan melatih anggota tersebut menjadi lebih professional. Sekaligus penerapan aplikasi sistem informasi perencanaan, penganggaran dan laporan (AMRAL) alat bantu dalam APBD mulai dari musrenbang tingkat kelurahan, kecamatan, dan Organisasi Perangkat Daerah (OPD).

\section{Sosialisasi Internal Pencegahan Korupsi}

Sosialisasi internal pencegahan korupsi di lingkungan pemerintah kota Tangerang Selatan yang digelar oleh Inspektorat kota Tangerang Selatan pada hari selasa, 12 April 2017 di ruang akhlakul karimah. Yang bertujuan menginformasikan tetang penegakan korupsi dan gratifikasi di lingkungan Tangerang Selatan, serta meningkatkan kesadaran seluruh anggota pemerintahan kota Tangerang Selatan.

\section{Rencana aksi program pemberantasan korupsi}

Aksi terintegrasi Pemerintah Kota Tangerang Tahun 2016 dan satuan tugas pelaksana rencana aksi, yang dituangkan dalam Keputusan Wali Kota

27 Kota Tangerang Selatan, "Pemkot Tangsel Perkuat Pencegahan Korupsi" diakses tanggal 26 Aprill 2018 pukul 16.30 WIB dari https://metaonline.id/pemkot-tangsel-perkuatpencegahan-korupsi/ 
Nomor: 800/Kep.506-Inspektorat/2016. Melalui E-Planning, E-Budgeting, dan Pelayanan Terpadu ${ }^{28}$.

\section{a. E-Planning}

Yaitu sebuah alat penyusunan RKPD, KUA PPAS, KUA/PPAS Perubahan, RKPD Perubahan Kabupaten/Provinsi agar dapat terselesaikan dengan mudah, cepat, tepat dan sesuai dengan arahan yang terkandung dalam Permendagri No. 54 Tahun 2010. Dengan adanya alat bantu e-planning, BAPPEDA dapat memaksimalkan sistem dan sistem juga mampu menyajikan analisa yang sangat informatif bagi para pemangku kepentingan.

\section{b. E-budgeting}

Merupakan sebuah sistem keuangan yang disimpan secara online dengan tujuan transparansi bagi setiap pihak. Sistem ini diterapkan sebagai dokumentasi penyusunan anggaran di sebuah daerah. Setiap orang bisa mengakses data-data anggaran yang disusun oleh sebuah pemerintah daerah sehingga diharapkan bisa mencegah upaya penggelapan dana atau kecurangan dari birokrasi setempat. Keunggulan Sistem E-Budgeting Sistem e-budgeting kini pun mulai membuktikan sejumlah keunggulannya dibandingkan dengan penerapan dokumentasi keuangan secara konvensional. Beberapa keunggulannya seperti: Mencegah tindakan korupsi, Prinsip Transparansi Publik, Efisiensi Pendataan Keuangan.

c. Pelayanan Terpadu

Pelayanan Terpadu Satu Pintu merupakan Pelayanan yang dilakukan oleh Pemerintahan baik perizinan maupun non perizinan, yang proses pengelolaannya dimulai dari tahap Permohonan sampai terbitnya sebuah dokumen dilakukan di dalam satu tempat. BPTSP Bertugas melaksanakan Monitoring, Pembinaan, Evaluasi, dan Pengendalian terhadap Penyelenggaraan PTSP yang dilakukan Kantor PTSP, Satlak Kecamatan dan Satlak Kelurahan, juga melakukan pelayanan dan Penandatanganan Perizinaan dan Non Perizinan.

Kantor PTSP ini bertugas melakukan pengendalian terhadap Satlak Kecamatan, serta melakukan pelayanan dan Penandatanganan Perizinan maupun non perizinan, juga dokumen-dokumen yang menjadi kewenangannya. Tugas dari Satlak Kecamatan adalah melakukan Pelayanan dan Penandatanganan terhadap Perizinan dan Non Perizinan serta dokumen sesuai kewenangannya. Lalu tugas dari Satlak Kelurahan

\footnotetext{
28 Pemerintah Kota Tangerang Selatan, "Upaya pencegahan KKN" diakses tanggal 5 Mei 20178 pukul.20.00 WIB http://tangerangkota.go.id/pemkot-tangerang-paparkan-rencana-aksipemberantasan-korupsi-terintegrasi.
} 
sama seperti Satlak Kecamatan, bedanya hanya bagian kewenangannya saja.

\section{Kerjasama dengan Pemerintah Provinsi Banten}

Pemerintah Provinsi Banten merumuskan enam aksi pencegahan korupsi, yaitu diantaranya pengelolaan APBD, pengadaan barang dan jasa, optimalisasi pendapatan, pelayanan perijinan, pengembangan SDM dan pembinaan pengawasan. Hal ini diselenggarakan bekerjasama dengan KPK (Komisi Pemberantasan Korupsi). Selain rencana aksi yang dituangkan dalam keputusan gubernur, tim Koordinasi dan Supervisi Pencegahan Korupsi (Korsupgah KPK) dan Pemprov Banten telah merumuskan rencana aksi yang bersifat tematik. Diantaranya membahas permasalahan ketahanan pangan melalui pengelolaan irigasi terkoordinasi antar SKPD dan Kementrian Pekerjaan Umum, tematik Banten Cyber sebagai infrastruktur pendukung dalam pelaksanaan $E$ government, pendidikan, kesehatan, aset, infrastruktur dan tematik data bekerjasama dengan Bank Indonesia dan Badan Pusat Statistik.

\section{Kerjasama dengan KPK (Komisi Pemberantasan korupsi)}

Sejak Tahun 2015 pemerintah kota Tangerang Selatan telah bekerjasama dengan Komisi Pemberantasan Korupsi (KPK) dalam upaya penanggulangan korupsi dan gratifikasi yang diimplementasikan melalui sosialisasi kepada pegawai negeri di lingkungan Tangerang Selatan.

Pemberian user ID e-resses dan passwordnya kepada anggota DPRD Tangerang Selatan dari KPK. MoU dengan KPK itu menyangkut penggunaan APBD, melalui sektor pengadaan barang dan jasa. Langkah ini dinilai cukup efektif, guna mencegah terjadinya KKN di seluruh Satuan Kerja Perangkat Daerah (SKPD) yang ada di daerah tersebut. Tim KPK akan memberikan pendidikan dan pelatihan kepada seluruh pegawai dan pejabat yang terlibat langsung dalam penggunaan anggaran daerah. Tak hanya itu, mereka juga akan mengawasi langsung jalannya pembangunan dan pengalokasian uang rakyat tersebut. Sehingga, penyelewengan serta permainan curang yang dilakukan para pengguna dengan pihak swasta dapat terkontrol dan diminimalisir.

Penandatanganan pakta integritas bertujuan agar dalam pelaksanaan seluruh tugas dan fungsi, tanggung jawab, wewenang dab peran sesuai aturan yang ada. Ada dua nilai dalam 'integritas' ini. Integritas Eksternal dan Integritas Internal. Intergritas Eksternal dibagi dalam tiga bagian yaitu indeks korupsi, indeks trsparansi, dan indeks akuntabilitas. Sedangkan Integritas Internal terbagi menjadi dua bagian yaitu Integritas Budaya dan Integritas Kerja, yang merupakan bentuk dasar pijakan dalam penilaian integritas. kegiatan ini bertujuan memberikan pemahaman dan pendidikan kepada semua pihak agar tidak terjebak pada pemahaman yang keliru tentang apa itu korupsi, dan dari 
sudut Direktorat Penelitian dan Pengembangan KPK sendiri itu merupakan langkah preventif dari pencegahan korupsi. ${ }^{29}$. Pejabat kerap mendapatkan hadiah dalam berbagai bentuk seperti uang atau barang dalam membantu proses perizinan. Kedepannya, Pemkot Tangsel pun akan berkoordinasi dengan KPK dalam membentuk unit pengendalian gratifikasi.

\section{Kebijakan Hukum Pencegahan Korupsi dan Gratifikasi Di Pemerintahan Kota Tangerang Selatan}

Pada paragraf berikut ini dipaparkan tentang penyusunan kebijakan hukum, sosialisasi dan legitimasi kebijakan hukum, serta implemntasi kebijakan hukum tentang pencegahan korupsi dan gratifikasi di Kota Administratif Tangerang Selatan.

\section{Penyusunan kebijakan hukum pencegahan korupsi dan gratifikasi}

Kebijakan hukum atau peraturan daerah kabupaten/kota dibentuk oleh DPRD kabupaten/kota bersama bupati/walikota, sesuai dengan mekanisme yang ditentukan dalam peraturan perundang-undangan untuk dibahas bersama dan untuk mendapat persetujuan bersama terhadap rancangan peraturan daerah sebelum disahkan menjadi peraturan daerah. Peraturan Daerah adalah semua peraturan yang dibuat oleh pemerintah setempat untuk melaksanakan peraturan-peraturan lain yang lebih tinggi derajatnya. Oleh karena itu materi peraturan daerah secara umum memuat antara lain: ${ }^{30}$

a. Hal-hal yang berkaitan dengan rumah tangga daerah dan hal-hal yang berkaitan dengan organisasi pemerintah daerah.

b. Hal-hal yang berkaitan dengan tugas dan pembantuan, dengan demikian Perda merupakan produk hukum dari pemerintah daerah dalam rangka melaksanakan otonomi daerah, yaitu melaksanakan hak dan kewenangan untuk mengatur dan mengurus urusan rumah tangga sendiri sekaligus perda merupakan legalitas untuk mendukung Pemerintah Provinsi sebagai daerah otonom.

Dalam rangka membuat peraturan perundang-undangan maupun peraturan daerah terdapat tiga dasar sebagai berikut: ${ }^{31}$

a. Landasan Filosofis, perundang-undangan dihasilkan mempunyai landasan filosofis (filisofische groundslag) apabila rumusannya atau norma-

${ }^{29}$ Penanggulangan KKN di Tangsel, "Kerjasama KPK dengan tangsel” diakses tanggal 10 April 2018 pukul.21.00 WIB dari https://kabartangsel.com/tag/kpk/

${ }^{30}$ Rosidi Ranggawidjaja, Pengantar Ilmu Perundang-undangan Indonesia, (Bandung: Mandar Maju, Bandung, 1998), h.23.

31 Bagir Manan, Dasar-dasar perundang-undangan Indonesia, (Jakarta: Ind-Hill Co, 1992), h.54. 
normanya mendapatkan pembenaran (Rechtvaardiging) dikaji secara filosofis. Jadi undang-undang tersebut mempunyai alasan yang dapat dibenarkan apabila dipikirkan secara mendalam.

b. Landasan Sosiologis, suatu perundang-undangan dikatakan mempunyai landasan sosiologis (sociologische groundslog) apabila ketentuanketentuannya sesuai dengan keyekinan atau kesadaran hukum masyarakat.

c. Landasan Yuridis, landasan yuridis (Rechtground) atau disebut juga dengan landasan hukum adalah dasar yang terdapat dalam ketentuanketentuan hukum yang lebih tinggi derajatnya. Landasan yuridis dibedakan pula menjadi dua macam, yaitu :

d. Segi formal adalah ketentuan hukum yang memberikan wewenang kepada badan pembentukkannya

e. Segi material adalah ketentuan-ketentuan hukum tentang masalah atau persoalan apa yang harus diatur.

Berdasarkan hasil penelitian yang telah dilakukan peneliti, maka dapat diambil kesimpulan bahwa proses penyusunan yang telah dilakukan oleh pemerintah kota Tangerang Selatan telah disusun sesuai tata aturan yang berlaku. Dimana sebelum kebijakan tersebut dibuat maka diajukan terlebih dahulu rancangan kebijakannya, dalam hal ini Peraturan Walikota dan Keputusan Walikota tentang pengendalian gratifikasi.

Kemudian draft Peraturan walikota dari SKPD (Satuan Kerja Perangkat Daerah) dan OPD (Organisasi Perangkat Desa) atau inisiatif dari bagian hukum, dapat diajukan dari inspektorat dan kemudian dibentuk sebuah tim untuk menyusun draft dan draftnya akan dibahas oleh bagian hukum dan juga oleh pejabat pemerintah bersangkutan.

Keputusan walikotan dan Peraturan walikota mengenai gratifikasi ini diajukan dari inspektorat kemudian membentuk tim dan menyusun draft dan draft tersebut di bahas oleh bagian hukum dan juga oleh pejabat pemerintah bersangkutan. Selain oleh bagian hukum, juga oleh BPKP dan draft itu dimasukan oleh bagian hukum dan di proses sampai kemudian disetujui dan ditandatangani oleh walikota dan resmi menjadi Perwal dan Kepwal.

\section{Sosialisasi dan legitimasi kebijakan hukum korupsi dan gratifikasi}

Sosialisasi menurut kamus besar Bahasa Indonesia berarti upaya memasyarkatkan sesuatu sehingga menjadi dikenal, dipahami, dihayati oleh masyarakat atau pemasyarakatan. ${ }^{32}$ Sosialisasi dapat diartikan sebagai aktivitas yang ditunjukkan untuk memberitahukan membujuk atau mempengaruhi

32 Kamus Besar Bahasa Indonesia, Kamus versi online/Dalam Jaringan. Diakses dari https://kbbi.web.id/sosialisasi diakses pada 5 Mei 2018 pukul 20.00 wib. 
masyarakat untuk tetap menggunakan produk dan jasa yang dihasilkan itu. Kemudian, Dalam kaitannya dengan kegiatan sosialisasi yang dimaksud adalah suatu proses memberitahukan dan memperngaruhi masayarakat untuk selalu memanfaatkan jasa-jasa yang ditawarkan.

Berdasarkan hasil penelitian yang telah dilakukan peneliti, maka dapat diambil kesimpulan bahwa proses sosialisasi dan legitimasi yang telah dilakukan oleh pemerintah kota Tangerang Selatan telah disusun sesuai tata aturan yang berlaku walau masih belum sempurna. Sosialisasi yang dilakukan pemerintah kota Tangerang Selatan tidak secara langsung memberikan sebuah penjelasan mengenai kebijakan yang dibuat kepada masyarakat, namun segala kebijakan yang dibuat oleh pemerintah kota Tangerang Selatan telah di unduh di website resmi pemerintah kota Tangerang Selatan sehingga dirasa tidak dibutuhkannya sosialisasi secara langsung kepada masyarakat.

Selain itu melainkan proses pemerintahan yang sudah partisipatif dengan melalu Muslembang yang dapat diakses secara online di wesite resmi pemerintah kota Tangerang Selatan sehingga masyarakat dapat memantau usulan-usulannya yang sudah dilaksanakan maupun tidak dari Musrenbang tingkat RT dan RW kelurahan atau tingkat kecamatan, sehingga akuntabilitasnya sudah melalui itu. Secara internal di UPG (Unit Pengendalian Gratifikasi) sudah dilakukan sosialisasi dengan peserta mulai dari kepada UPD (Unit Perangkat Desa) sampai staf-stafnya. Namun, dari masyarakat secara langsung belum dilakukan, seperti mengundang masyarakat dll.

Legitimasi adalah keterangan yang mengesahkan atau membenarkan bahwa pemegang keterangan adalah betul-betul orang yang dimaksud atau pernyataan yang sah (menurut undang-undang atau sesuai dengan undangundang). ${ }^{33}$ Dapat dikatakan bahwa legitimasi adalah pengakuan sebuah aturan yang dibuat pemerintah oleh masyarakatnya.

Legitimasi kebijakan hukum pemerintah kota Tangerang Selatan sesuai dengan prinsip aturan itu ketika ditetapkan maka tahu tidak tahu dan mau tidak mau maka harus dipatuhi. Namun secara kelembagaan kota Tangerang Selatan sudah memiliki JDIH yang ada di website resmi pemerintah kota Tangerang Selatan, jadi sudah diumumkan secara tidak langsung.

\section{Implementasi kebijakan hukum pencegahan korupsi dan gratifikasi}

Berdasarkan hasil penelitian, maka dapat dikatakan bahwa implementasi kebijakan hukum pemerintah kota Tangerang Selatan telah berjalan dengan baik,

33 Kamus Besar Bahasa Indonesia, Kamus versi online/Dalam Jaringan. Diakses dari https://kbbi.web.id/legitimasi diakses pada 5 Mei 2018 pukul 20.00 wib. 
walaupun terdapat beberapa hal yang masih perlu diperbaiki agar dapat semakin maksimal dalam upaya pencegahan korupsi dan gratifikasi.

Sejak tahun 2015 dimana mulai diberlakukannya Peraturan Walikota (Perwal) dan Keputusan Walikota (Kepwal) di pemerintah kota Tangerang Selatan sudah ada yang melaporkan gratifikasi yang diterima oleh beberapa ASN atau pejabat pemerintah kota Tangerang Selatan, baik yang dilakukan oleh wali kota atau wakilnya juga ikut serta melaporkannya. Sehingga implementasi dari Peraturan Walikota (Perwal) dan Keputusan Walikota (Kepwal) di pemerintah kota Tangerang Selatan sudah memiliki hasil walaupun belum maksimal.

Selain itu juga Unit Pengendalian Gratifikasi (UPG) menyediakan kotak untuk pelaporan tindak gratifikasi yang selalu di pantau, namun keberadaan kotak tersebut kurang efektif karena belum banyak pegawai yang melapor. Hal ini terjadi karena memang kultur atau kebiasaan masyarakatnya yang masih terbiasa memberi dan menerima gratifikasi. Sehingga gratifikasi masih dianggap sebagai hal yang biasa saja dilakukan dan tidak perlu dilaporkan.

\section{Kesimpulan}

Dari paparan pada paragraf-paragraf di atas, dapat diambil beberapa kesimpulan dari makalah ini, antara lain:

Pertama; Pemerintah Kota Administratif Tangerang Selatan telah melakukan upaya-upaya pencegahan korupsi dan gratifikasi yaitu dengan Penerbitan Peraturan Walikota Nomor 17 Tahun 2017 tentang pedoman pengendalian gratifikasi dan Keputusan Walikota Nomor 700/Kep.188-Huk/2015 tentang pembentukan unit pengendalian gratifikasi.yang mengatur tentang gratifikasi, pembentukan unit pengendalian gratifikasi, pembentukan tunas anti korupsi, optimalisasi kinerja apip (aparat pengawasan internal pemerintah), sosialisasi internal, rencana aksi program pemberantasan korupsi melalui $e$ planning, e-budgeting, pelayanan terpadu, kerjasama dengan pemerintah provinsi banten, dan kerjasama dengan KPK (Komisi Pemberantasan korupsi).

Kedua; Tingkat keberhasilan upaya-upaya pencegahan korupsi dan gratifikasi di Pemerintahan Kota Administratif Tangerang Selatan dapat disimpulkan telah efektif, karena telah dapat mengurangi tingkat tindak pidana koruspi dan gratifikasi secara cukup signifikan. Meskipun begitu, masih terdapat hal-hal yang harus disempurnakan, seperti penempatan kotak pelaporang korupsi dan gratifikasi yang belum banyak diketahui oleh masyarakat, paradigma masyarakat tentang pencegahan korupsi dan gratifikasi masih perlu diubah dan lain sebagainya.

Ketiga; Terdapat beberapa kendala yang dihadapi oleh Pemerintah Kota Administratif Tangerang Selatan dalam rangka pencegahan korupsi dan 
gratifikasi, misalnya pendidikan agama dan etika yang masih perlu dibenahi, keserakahan para pemangku jabatan masih perlu dianulir, sanksi terhadap pelaku tindak pidana korupsi dan gratifikasi yang masih perlu dipertegas, penempatan pejabat pemerintahan Kota Tangerang Selatan masih perlu disesuaikan dengan kompetensinya, serta sosialisasi peraturan tentang pencegahan korupsi dan gratifikasi masih perlu diperluas.

\section{Daftar Pustaka}

Bambang, Sunggono. Hukum dan Kebijakan Publik. Jakarta: Sinar Grafika, 1994.

Chazawi, Adami. Hukum Pidana Materil dan Formil Korupsi di Indonesia,. Malang: Bayumedia Publishing, 2005.

Hadayadiningrat, Soewarno. Pengantar Studi Ilmu Administrasi dan Management. Jakarta: Yayasan Idayu, 1980.

Hafidz Arsyad, Jawade. Korupsi dalam Prespektif HAN (Hukum Administrasi Negara). Jakarta: Sinar Grafika, 2013.

Hamzah, Andi. Korupsi di Indonesia Masalah dan Pemecahannya, Jakarta: PT Gramedia, 1984.

Hamzah, Jur. Andi. Pemberantasan Korupsi Melalui Hukum Pidana Nasional dan Internasional. Jakarta: PT Raja Grafindo Persada, 2007.

Kaligis, O.C. Dasar Hukum Mengadili Kebijakan Publik. Bandung: P.T. Alumni, 2012.

Kligaard, Robert, dkk. Menuntun Pemberantasan Korupsi (dalam pemerintah daerah). Jakarta: Yayasan Obor Indonesia, 2005.

Komaruddin, Ensiklopedia Managemen, cet ke-1. Jakarta: Bumi Aksara, 1994.

Komisi Pemberantasan Korupsi. Buku Saku Memahami Gratifikasi. Jakarta: Komisi Pemberantasan Korupsi Republik Indonesia, 2014.

Lopa, Baharuddin. Kejahatan Korupsi dan Penegakan Hukum. Jakarta: PT Kompas Media Nusantara, 2001.

Maheka, Arya. Mengenal dan Memberantas Korupsi. Jakarta: Veteran III, tt.

Manan, Bagir. Dasar-dasar perundang-undangan Indonesia. Jakarta: Ind-Hill Co, 1992.

Martoyo, Managemen Sumber Daya Manusia, Edisi ke-5. Yogyakarta: BPFE, 2000.

Nawawi Arief, Barda. Kapita Selekta Hukum Pidana, cet. Ke-I. Bandung: Citra Aditya Bakti, 2003.

Nugroho, Riant. Metode Penelitian Kebijakan. Yogyakarta: Pustaka Pelajar, 2013.

P. Robbins, Stephen, A. Judge Timothy. Perilaku Organisasi (Organizational Behavior), Buku 1, Penerjemah Diana Angelica, Ria Cahyani dkk, Edisi 12. Jakarta: Salemba Empat, 2008.

P. Sibuea, Hotma. Asas Negara Hukum Peraturan Kebijakan dan Asas-asas Umum Pemerintahan yang Baik, Jakarta: Penerbit Erlangga, 2010. 
Pope, Jeremy. 2003. Strategi Memberantas Korupsi (Edisi Ringkas) dengan judul asli Confloring Corruption: Element of Nation Integrity System, by Jeremy Pope. Diringkas oleh TJahjono EP. Jakarta: Transparancy International Indonesia

Prasetyo, Pius S. Korupsi dan Integritas Dalam ragam Perspektif. Jakarta: Pusat Studi Indonesia-Arab PSIA, 2013.

Prinst, Darwan. Pemberantasan Tindak Pidana Korupsi. Bandung: PT. Citra Aditya Bakti, 2002.

Ranggawidjaja, Rosidi. Pengantar Ilmu Perundang-undangan Indonesia. Bandung: Mandar Maju, 1998.

Ridwan HR. Hukum Administrasi Negara. Jakarta: PT Raja Grafindo Persada, 2006.

Ruslan, Dadan. Gratifikasi Dalam Tinjauan Hukum Islam. Skripsi S1 Universitas Islam Neger Syarf Hidayatullah Jakarta, 2014.

Saidi, Anas, dkk. Pemberantasan Korupsi Dan Pemerintahan Yang Bersih. Jakarta: LIPI Press.,2006.

SF Marbun. Peradilan Administratif Negara dan Upaya Administratif di Indonesia. Yogyakarta: FH UII Press, 2011.

Soekanto, Soejono dan Sri Mamudji. Penelitian Hukum Normatif (suatu tinjaun singkat). Jakarta: Rajawali Press, 2011.

Soekanto, Soejono. Penelitian Hukum Normatif. Jakarta: PT. Raja Grafindo Persada, 2010.

Sunindhia, Y.W. Praktek Penyelenggaraan Pemerintah di Daerah. Jakarta: PT Rineka Cipta, 1996.

Surachmin, Suhandi Cahaya. Strategi \& Teknik Korupsi mengetahui untuk mencegah. Jakarta: Sinar Grafika, 2013.

Tim Redaksi Fokus Media. Himpunan Peraturan Peundang-Undangan dengan Pemberantasan Tindak Pidana Korupsi. Bandung: Fokus Media, 2008.

Wibawa, Samodra dkk. Evaluasi Kebijakan Publik. Jakarta: PT Raja Grafindo Persada, 1992.

\section{Bahan Perundang-Undangan}

Keputusan Walikota Tangerang Selatan Nomor 700/Kep.188-Huk/2015, Tentang Pembentukan Unit Pengendali Gratifikasi Di Lingkungan Kota Tangerang Selatan

Peraturan Walikota Nomor 17 Tahun 2017 Tentang Pedoman Pengendalian Gratifikasi

Undang-Undang Nomor 23 Tahun 2014 Tentang Pemerintahan Daerah

Undang-Undang Nomor 29 Tahun 1999 Tentang Penyelenggaraan Negara Yang Bersih Dan Bebas Dari Korupsi, Kolusi Dan Nepotisme

Undang-Undang Nomor 31 Tahun 1999 Tentang Pemberantasan tindak Pidana Korupsi

Undang-Undang Nomor 32 Tahun 1999 Tentang Pemberantasan Tindak Pidana Korupsi 


\section{Bahan Online}

https://www.republika.co.id/berita/nasional/hukum /18/06/22/papygi409-kpkterima-798-laporan-gratifikasi-senilai-rp-72-miliar (Sabtu 23 June 2018 02:18 WIB).

Kamus Besar Bahasa Indonesia (KBBI) Dalam Jaringan. Diakses dari https://kbbi.web.id/legitimasi diakses pada 5 Mei 2018 pukul 20.00 wib.

Komisi Pemberantasan Korupsi, Laporan Tahunan 2015 "Menolak Surut", (Jakarta: Tim Penyusun Laporan Tahunan KPK, 2015). diakses tanggal 23 April 2018 pukul.20.00 WIB dari https://www.kpk.go.id

Komisi Pemberantasan Korupsi, Laporan Tahunan 2016 "Hingga Kebawah Permukaan". diakses tanggal 23 April 2018 pukul.20.00 WIB dari https://www.kpk.go.id

Komisi Pemberantasan Korupsi, Laporan Tahunan 2017 "Dari Indonesia untuk Indonesia". diakses tanggal 23 April 2018 pukul.20.00 WIB dari

https://www.kpk.go.id

Kota Tangerang Selatan, "Pemkot Tangsel Perkuat Pencegahan Korupsi" diakses tanggal 26 Aprill 2018 pukul 16.30 WIB dari https://metaonline.id/pemkottangsel-perkuat-pencegahan-korupsi/

Kota Tangerang Selatan, "Profil Kota Tangerang Selatan" diakses tanggal 9 Maret 2018 pukul 16.30 WIB dari https://id.wikipedia.org/

Pemerintah Kota Tangerang Selatan, "Faktor Meningkatnya Korupsi” diakses tanggal 5 Mei 2018 pukul.20.00 WIB

https://www.tangerangselatankota.go.id/pemkot-tangerang-paparkanrencana-aksi-pemberantasan-korupsi-terintegrasi.

Pemerintah Kota Tangerang Selatan, "Letak Tangerang Selatan” diakses tanggal 9 Maret 2018 pukul 16.30 WIB dari https://www.tangerangselatankota.go.id

Pemerintah Kota Tangerang Selatan, "Sejarah Tangerang Selatan" diakses tanggal 9 Maret 2018 pukul 16.30 WIB dari https://www.tangerangselatankota.go.id

Pemerintah Kota Tangerang Selatan, "Upaya pencegahan KKN" diakses tanggal 5 Mei 20178 pukul.20.00 WIB http://tangerangkota.go.id/pemkottangerang-paparkan-rencana-aksi-pemberantasan-korupsi-terintegrasi.

Pemerintah Kota Tangerang Selatan, "Visi dan Misi Tangerang Selatan” diakses $\begin{array}{lllllll}\text { tanggal } 9 & 9 & \text { Maret } 2018 \text { pukul } 16.30 & \text { WIB dari }\end{array}$ https://www.tangerangselatankota.go.id

Penanggulangan KKN di Tangsel, "Kerjasama KPK dengan tangsel" diakses tanggal 10 April 2018 pukul.21.00 WIB dari https://kabartangsel.com/tag/kpk/

Supriyadi Ahmad, "Dari Mahar Politik hingga Mental Politik Transaksional: Kajian Komparatif Tentang Korupsi Di Era Milenial Indonesia", dalam Mizan: Jurnal Ilmu Syariah, FAI Universitas Ibn Khaldun UIKA Bogor Vol. 5 No.1, 2017. 


\section{Mizan}

MIZAN; JURNAL ILMU SYARIAH (ISSN: 2089-032X) adalah berkala ilmiah yang diterbitkan oleh Program Studi Akhwal al Syakhsyiyyah, Fakultas Agama Islam Universitas Ibn Khaldun Bogor. Mizan; Jurnal IImu Syariah mengkhususkan diri dalam pengkajian ilmu-ilmu Syariah, Hukum Keluarga dan Studi Islam. Terbit dua kali dalam satu tahun di setiap bulan Juni dan Desember.

Redaksi menerima artikel-artikel dari para sarjana, pemerhati, dan peneliti dalam bidang IImu Syariah untuk dipublikasikan setelah proses seleksi yang ketat, telaah mitra bestari, serta proses penyuntingan secara serius. Secara substantif, setiap artikel yang dipublikasikan dalam berkala ilmiah ini merupakan pandangan dan sekaligus akan dipertanggungjawabkan secara ilmiah oleh para penulisnya.

ARTIKEL-ARTIKEL MIZAN; JURNAL ILMU SYARIAH TELAH TERINDEKS DAN ONLINE PADA:

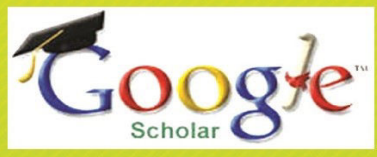

